\title{
Analysis of Surface and Magnetic Lineaments in and Around Wase Area of Northern Nigeria
}

\author{
Sanusi, Y. A. ${ }^{1^{*}}$ and Dahiru Dahuwa ${ }^{2}$ \\ ${ }^{I}$ Department of Physics, Usmanu Danfodiyo University, Sokoto, Nigeria \\ ${ }^{2}$ Department of Physics, College of Education Azare, Bauchi state Nigeria
}

\begin{abstract}
Aeromagnetic data over Wase and its adjoining areas were obtained and analyzed for delineation and analysis of magnetic (subsurface) and surface lineaments which often act as hosts or structural control on mineralization in basement areas. The magnetic lineaments were inferred from the colour shaded map of the first vertical gradient of the residual magnetic field. Lineament contour maps of the magnetic and surface lineaments showed correlation between the areas of highest lineaments density with the exposed basement areas and low lineament density with the sedimentary parts of the area. Also, the lineament length density maps of the surface and magnetic lineaments suggested that the study area was affected by different stress regimes of various intensities at different geological times.The rose diagram of the lineaments showed that the lineaments were oriented along NE-SW, E-W, NNE-SSW and NW-SE major trends and a minor trend along ENE-WSW direction and that some of the magnetic (subsurface) lineaments have propagated to the surface. Generally areas associated with lineaments in the high first vertical derivative gradient areas were recommended for further mineral investigations.
\end{abstract}

Keywords: first vertical derivative, lineament density, lineament length density, rose diagram, first Fourier transform.

\section{Introduction}

This study area, bounded between longitudes $9^{\circ}-10^{\circ}$ Eandlatitudes $9^{\circ}-10^{\circ} \mathrm{N}$ and covering parts of present Bauchi and Plateau states, is located within the northern Nigerian Basement Complex (NNBC) region (Fig.1). According to [1], the basement complex rocks of northern Nigeria are generally classified into three groups which include ancient meta-sediments, the gneiss - migmatites and the older granites with the gneiss migmatites complex covering about $30-50 \%$ of the basement complex area.Presence of gneiss - migmatites and granite suites were earlier reported ([2], [3]) within the study area. According to [4], these rocks were believed to originate from the remobilization that occurred during the Pan- African tectonic episode.

The surface geology map of the area (Fig. 2) shows that the dominant basement complex rocks comprises of migmatites, granites-biotites, migmatites-gneisses, granites- gneisses and basalts. The migmatites were observed to be deformed and intruded, in the central and southwestern part, by granites-biotites, migmatites-gneisses, granites- gneisses and basalts. Also, sediments shales and limestones were observed in the southeastern part of the study area. Recently in Nigeria, efforts have been geared towards exploration for mineral resources as a supplement to the available hydrocarbon deposits. Mineral exploration usually involves regional reconnaissance, surface and subsurface mapping, ground geophysical surveys and actual drilling [5]. Evidences from landsat studies in Nigeria [6] and information from the published mineral map of Nigeria (NGSA) showed that the NNBC is associated with primary mineral occurrences. Such minerals may include iron, gold, lead-zinc and uranium. Generally, primary mineralization of an area depends to a large extent on the structural geology of the host rock

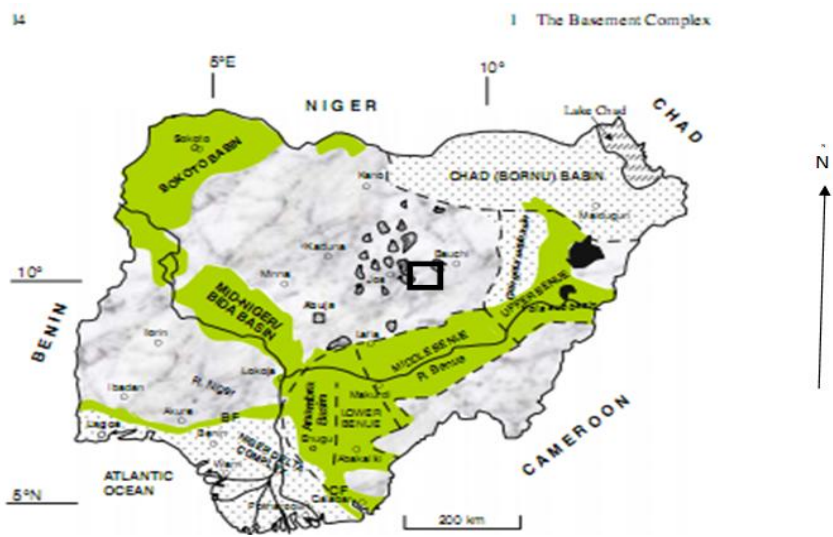

Fig. 1 Location Map of the Study Area showing the major Geologic components. 


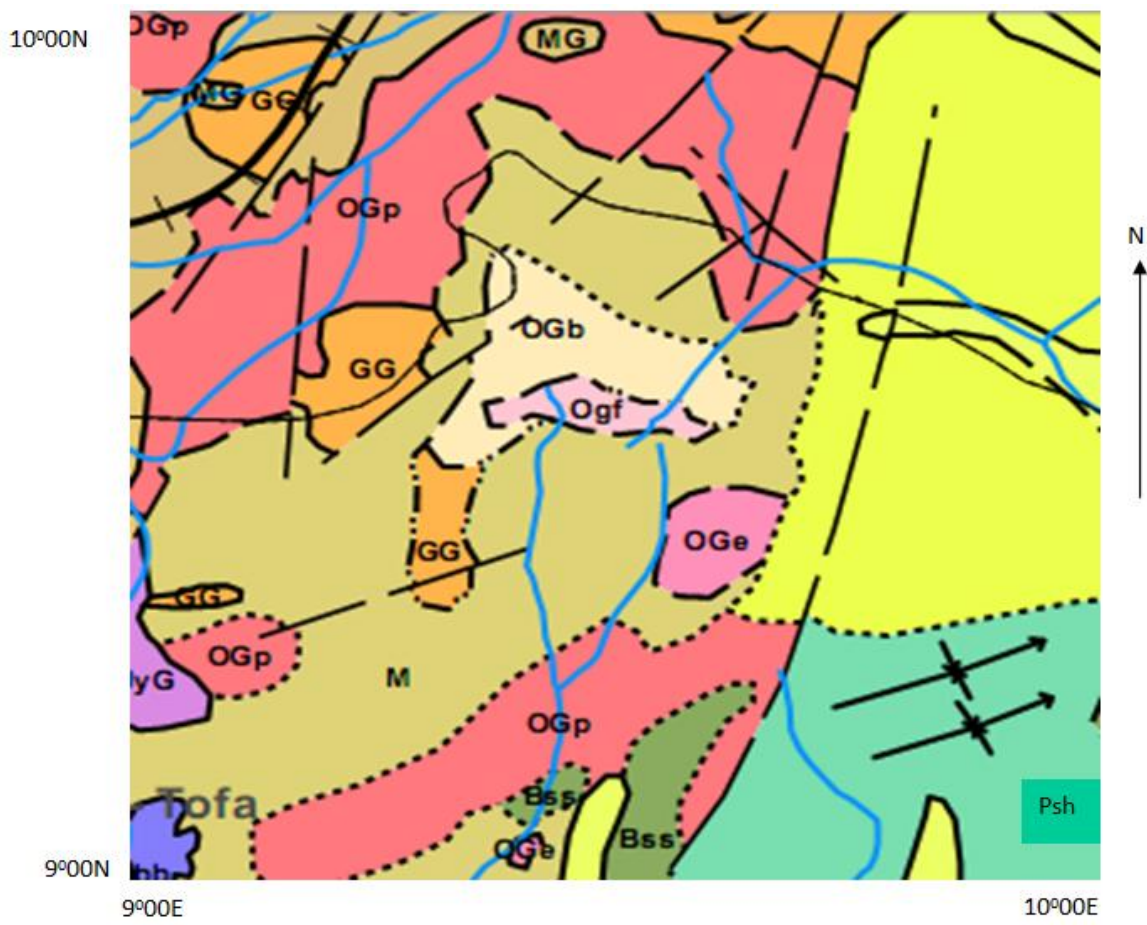

Fig. 2. Geologic Map of the Study Area

\section{LEGEND}

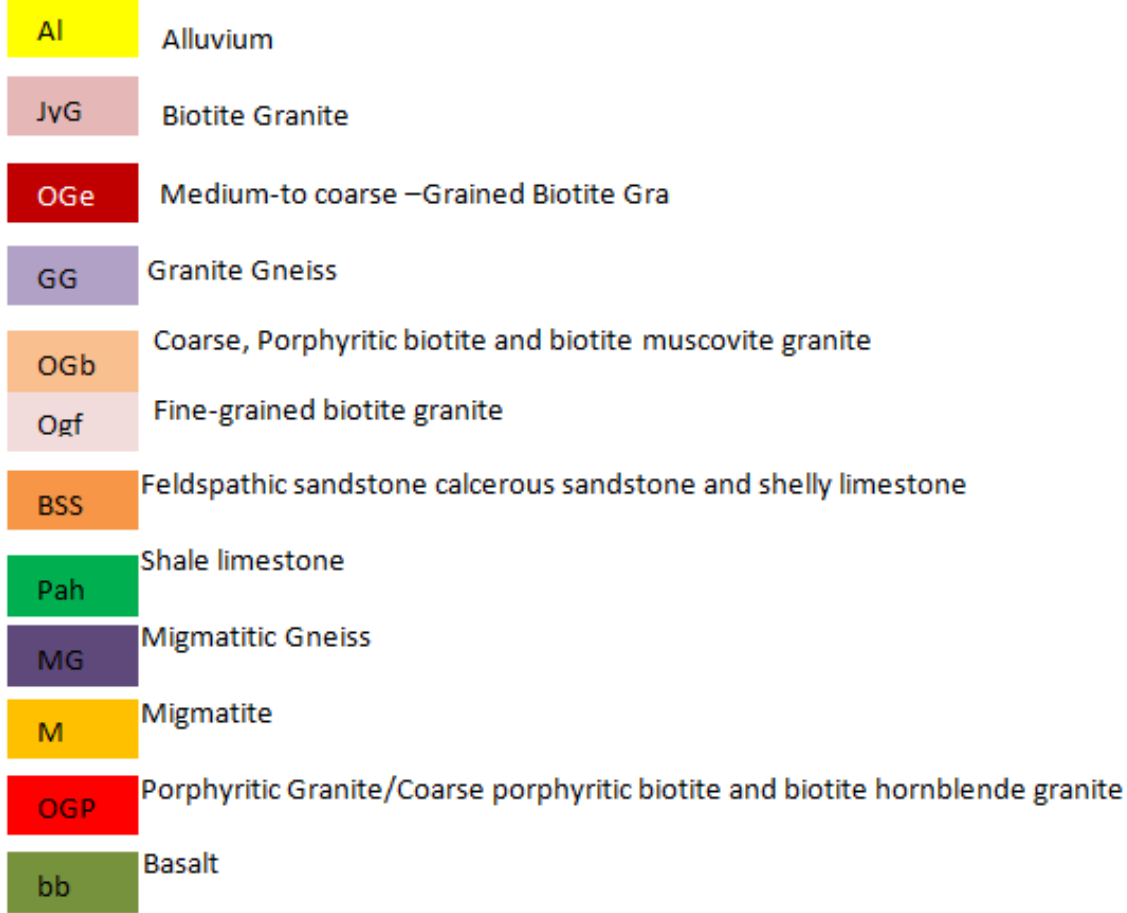

because the geologic structures control the emplacement and localization of the ore deposits [7]. Within the Nigerian basement complex region, correlations were observed between areas of high lineament density and mineral occurrence [6]. It is plausible therefore that prior to any mineral exploration programme, a comprehensive mapping of geologic structures should be embarked in the area.

Previous studies in the Nigerian basement complex region, using aeromagnetic data (e.g. [8], [9]) inferred presence of subtle regional NE-SW and ENE-WSW trending lineaments which were interpreted as possible Continental extension of the four Atlantic fracture zones (i.e. St Paul's, Romanche, Chain and Charcot) abutting the West African coast into the Nigerian basement complex. In the present study, aeromagnetic data over the study area will be utilized to infer and analyze the surface and subtle lineaments which may act as structural control on the mineralization occurrences in the area. 


\section{Source and treatment of magnetic data}

\section{Methodology}

The raw total-field magnetic intensity (TMI) data used in the study were recovered by digitizing four aeromagnetic maps published by the Nigerian Geological Survey Agency (NGSA). The maps, on a scale of 1:100,000, include; sheets 169 (Maijuju), 170 (Tafawa Balewa), 190 (Pankshin) and 191 (Wase). The raw data were collected as a result of nation-wide aeromagnetic survey conducted between 1974 to 1976 . The survey was flown at a nominal flight altitude of $154.2 \mathrm{~m}$ along approximately N-S flight lines spaced $2 \mathrm{~km}$ apart with tie lines at $20 \mathrm{~km}$ spacing interval.A plane surface, assumed to represent the regional field, was estimated using multilinear regression analysis and subtracted directly from the total-field magnetic intensity values to obtain the residual magnetic field intensity values of interest. Subsequently, the total-field magnetic intensity values and the estimated residual magnetic field intensity values were employed, using Surfer and Oasis Montage softwares, to obtain the contour and colour shaded maps of the total-field magnetic intensity and the residual field intensity values. Also, the surface lineament map of the study area was extracted from the lineaments map of Nigeria obtained from Nigerian Geological Survey Agency (NGSA).

\section{First Vertical Derivative}

First Vertical Derivative (FVD) represents one of the filters often employed in enhancing magnetic anomalies associated with shallow geologic features and to sharpen the edges of anomalies[10].Thus, the FVD method is employed to delineate shallow magnetic features more clearly when masked by low frequency anomalies associated with long wavelengths. The FVD is expressed [10]

$\mathrm{FVD}=\frac{\partial T}{\partial Z}$

where $\mathrm{T}$ is the potential field anomaly.

The practical procedure for estimating FVD values involves transforming the residual magnetic field intensity values into frequency domain, using first Fourier transform (FFT) method. The fast Fourier transformed data were then multiplied with a FVD filter, $K^{n}$, where $\mathrm{K}$ is the wavenumber and $\mathrm{n}$ is the filter order. Generally for a FVD filter the order is unity [11]. The product obtained was inverse Fourier transformed back to the space domain to obtain the FVD values. The estimation of derivatives is often associated with noise enhancement and to minimize this effect, the residual field data were continued upward to a height of $0.1 \mathrm{~km}$ prior to the estimation of the FVD values. The estimated FVD values were employed, using the Oasis Montaj software, to produce the colour shaded map of the FVD values over the study area. Following [12], trends of the lineaments associated with shallow structures were inferred by on-screen digitization of the trends of the FVD anomalies.

\section{Lineament Analysis}

To analyze the magnetic and surface lineaments in the study area, non- orientational and orientatational analyses of the surface and magnetic lineaments were performed. In the non- orientational analysis, the study area was partitioned into twenty-five square units and the density and mean lineaments length density analyses were performed. In the lineaments density analysis, the frequency of lineaments occurring within each sub-unit were counted while for the mean lineaments length density analysis, the total length of the lineaments within each sub-unit was estimated and divided by the area of the sub-unit as suggested by [13] and [14]. The lineament length density is expressed as [14]

$$
L_{D}=\frac{\sum L}{A}
$$

Where $L_{D}$ is the lineament length density, in $\mathrm{km}$, and $\mathrm{A}$ is the area, in $\mathrm{km}^{2}$.

In the orientation analysis, the azimuthal orientations of the lineaments, with respect to the geographic north, were measured. The trends were analyzed using rose diagrams which represent one of the common methods of analyzing lineament trends [15].

\section{Results And Discussion}

The colour shaded TMI map of the area, shown in Figure 3 , shows that the TMI values range between 32743 to $32942 \mathrm{nT}$ and were characterized by short wavelength (high wavenumber), medium wavelength (moderate wavenumber) and long wavelength (low wavenumber) anomalies. The map shows that the northeastern (NE) and the lower portions of the southwestern (SW) and northwestern (NW) parts were predominantly occupied by anomalies associated with high TMI values while the remaining portions of the area were occupied by anomalies associated 


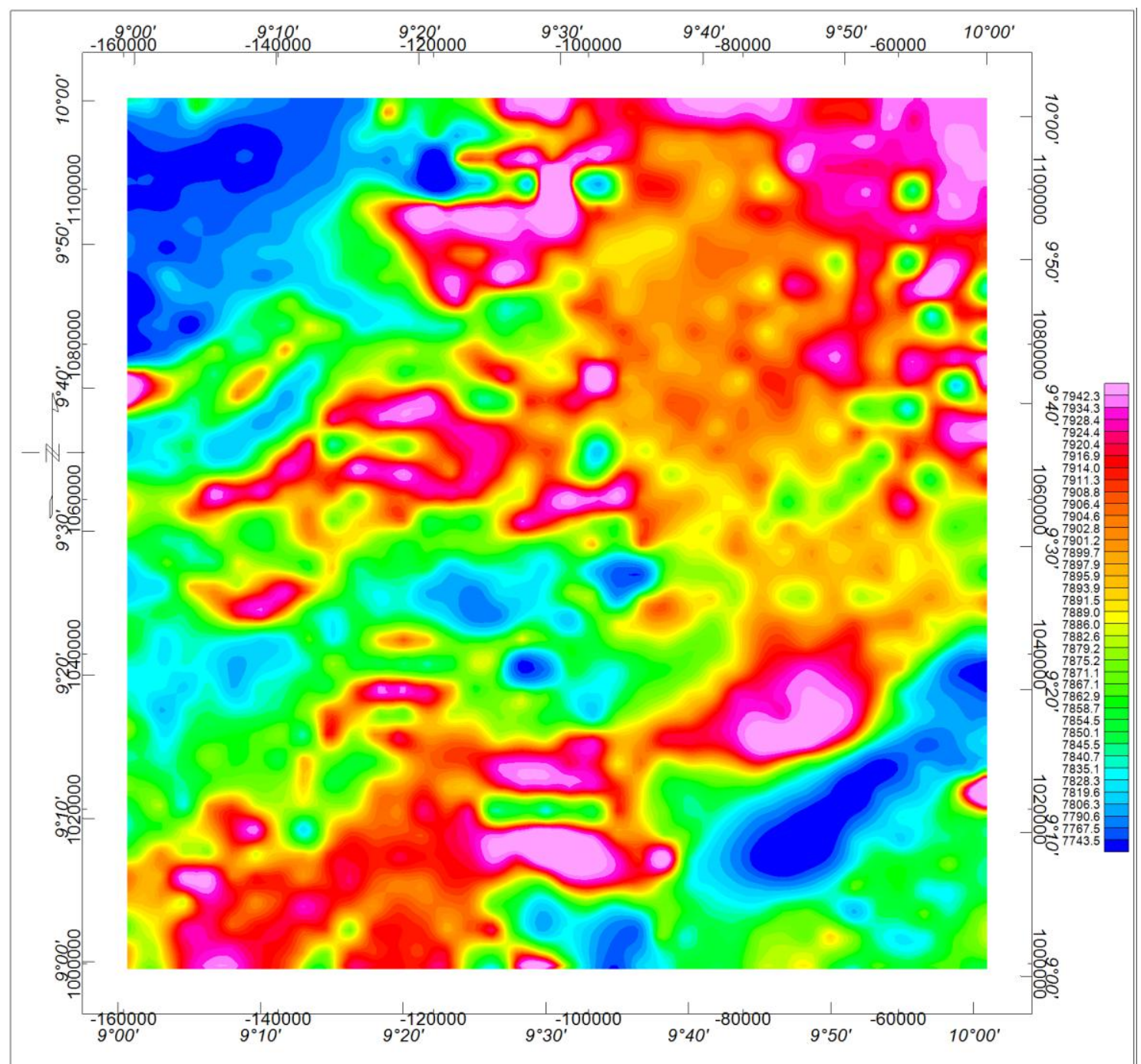

Fig 3. Colour Shaded Map of the Total Magnetic Field Intensity (TMI) Anomalies over the Study Area. (To obtain the Actual TMI values, 25,000 nT are to be added to the Values Shown in the Key).

with low TMI values. Furthermore, the map showed that the trends of the TMI anomalies were mostly oriented along NE-SW, E-W and NW-SE directions.

The colour shaded map of the residual magnetic intensity values (Fig. 4), which depicts the magnetic effects of the crustal rocks in the area, shows that the anomalies were associated with values ranging from -130 $\mathrm{nT}$ to $67 \mathrm{nT}$. The anomalies associated with moderate and high positive intensity values predominantly occupy the $\mathrm{NE}$ and the lower portions of the SW and NW parts while the remaining portions of the area were occupied by anomalies associated with negative values. Generally, areas associated with positive residual field intensity values correspond to areas of high TMI values and vice versa (see Fig.3). The trends of the residual magnetic field intensity anomalies were mostly oriented along NE-SW, E-W and NW-SE directions. Comparison between the residual field map and the surface geology shows correlation between areas associated with moderate and high positive residual magnetic intensity values with the exposed basement rocks while areas associated with negative values, in the SE part, correlates with the sedimentary formations in that portion.

The FVD map (Fig. 5) shows negative and positive gradient values evenly spread over the study area. The high gradient FVD anomalies were interpreted as near-surface or shallow basic igneous intrusions while the low gradient FVD anomalies were interpreted as igneous intrusions whose magnetizations were probably altered due to metamorphism. Correlation of areas associated with high gradient FVD anomalies with exposed basement rocks on the surface geology suggests the extrusion of the shallow magnetized intrusions to the surface. Historical knowledge and evidences from mineral map of Nigeria [6] suggested presence of mineralization in the study area. Therefore, areas associated with high gradient FVD anomalies may suggest 


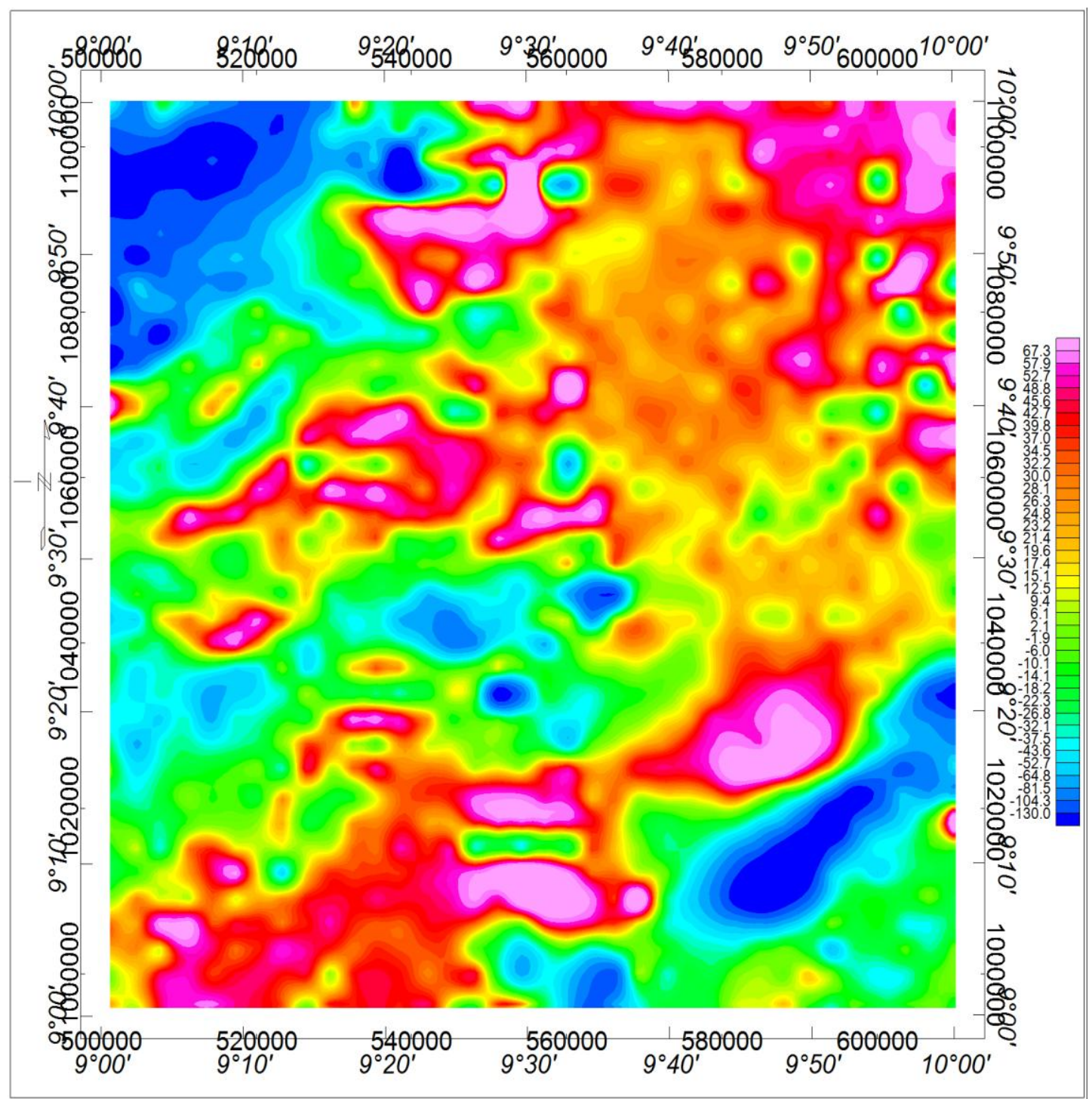

Figure 4. Colour Shaded Map of the Residual Magnetic Field Intensity Values over the Study Area.

association with mineralization. Visual inspection of the FVD map shows that the trends of the FVD anomalies were along NE-SW, NW-SE and E-W directions which correlates with trends of the TMI and residual fiels anomalies. Magnetic lineaments map (Fig. 6) inferred from the trends of the FVD anomalies and the surface lineament map (Fig. 7) shows that magnetic and surface lineaments were evenly distributed along different directions. The prevalence of lineaments in the exposed basement areas suggested that these fractures served as conduits for the ascension of the volcanic eruptions which later got solidified to form the exposed basement rocks. The lineament density contour pattern maps of the surface and magnetic lineaments (Figs. 8 and 9) showed an increase in the density of the lineaments from the northern and southern flanks towards the central portion of the western part of the area and a decrease in the density of lineaments from the central portion towards the eastern part of the study area. Generally the two maps showed a good correlationin terms of the pattern and shape of contours. As expected, areas associated with highest lineaments density in both maps correlate with the areas associated with exposed basement rocks while the sediments in the SE part were associated with low lineament density.

Results obtained from the lineaments length density of the magnetic and surface lineaments (Figs. 10 and 11) showed variations in the pattern of distribution of the magnitudes of the surface and magnetic lineament length densities in the study area. Comparison between the two maps did not show strong correlation in terms of pattern and magnitudes of the lineament length densities. According to [15], the variation in lineament length density pattern is attributed to the variations in tensional and compressional forces and the stress field intensity prevalent in basement regions. Thus, the weak correlation both in magnitude and contour patterns of the 


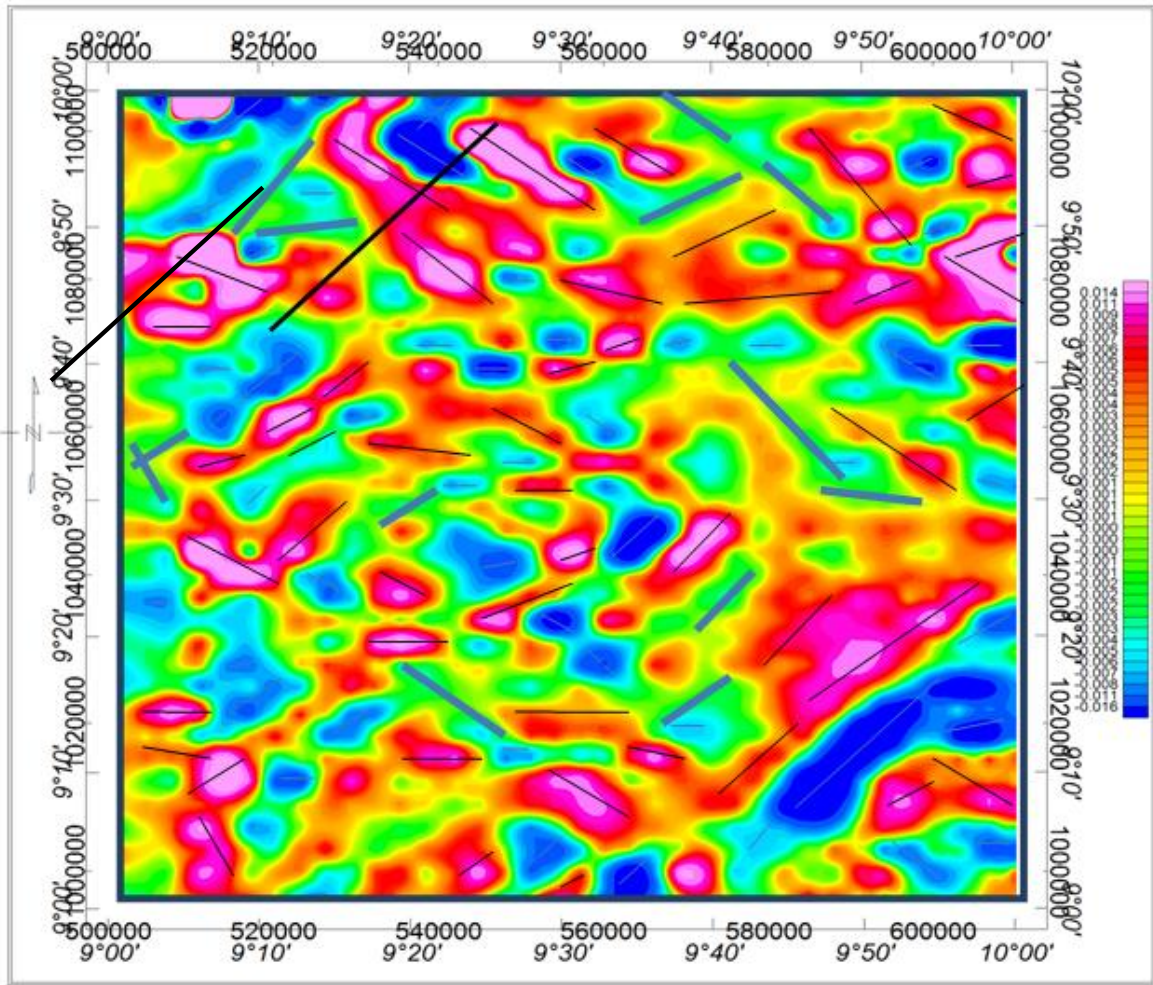

Fig 5. FVD Map of the Study Area with the Inferred Lineaments Superposed.

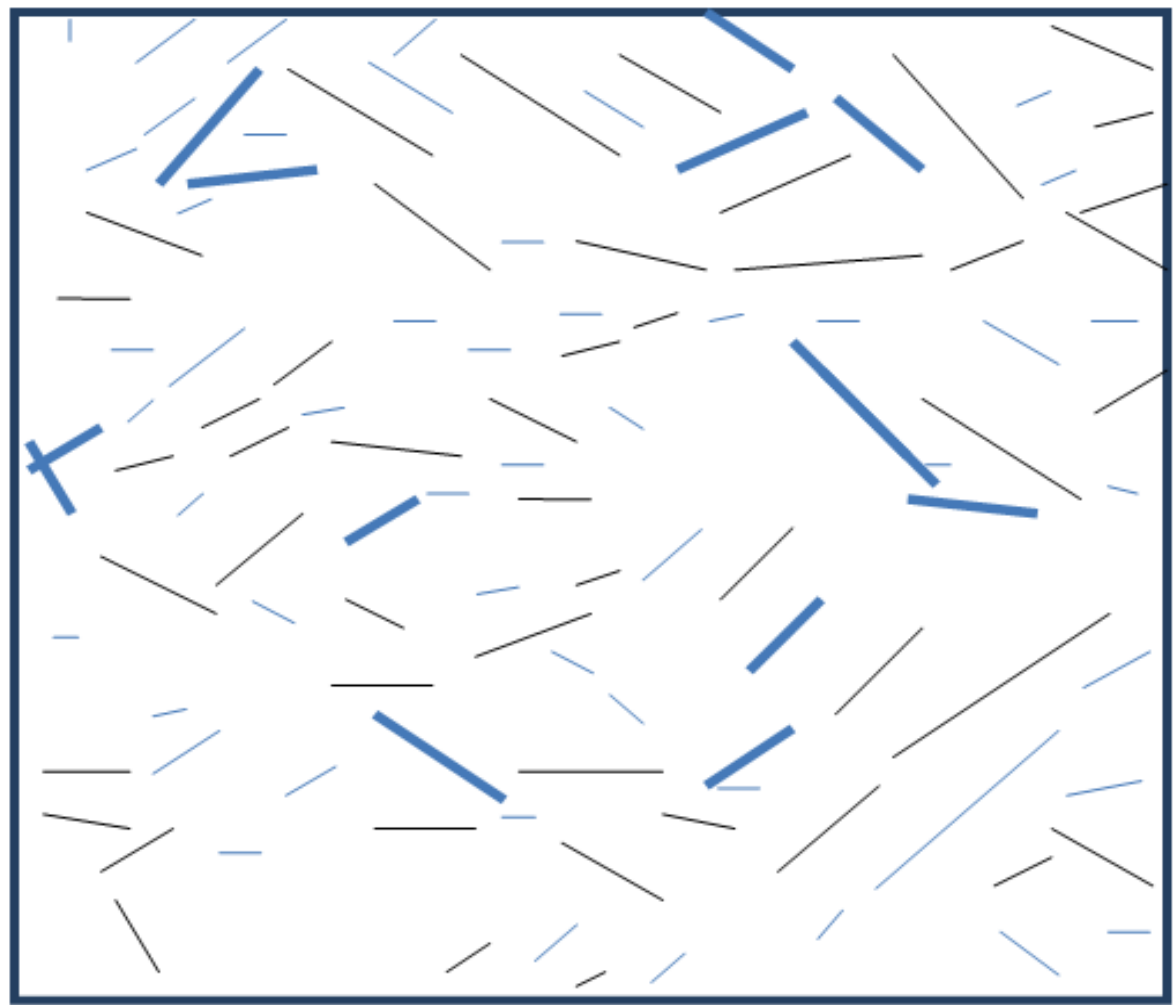

Fig.6. Magnetic Lineament Map of the Study Area. 


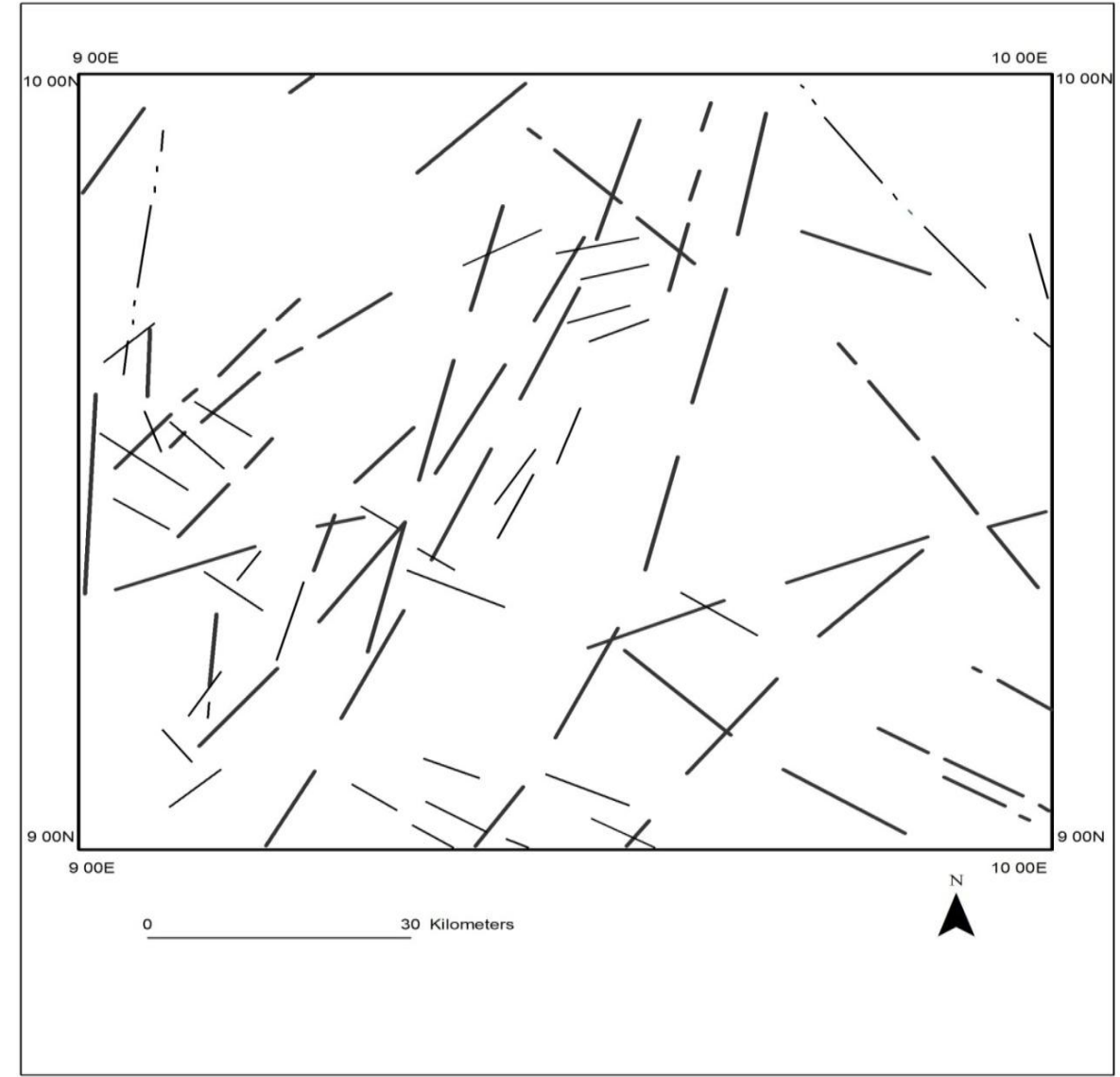

Fig. 7 Surface Lineament Map of the study Area (Source: NGSA, 1994)

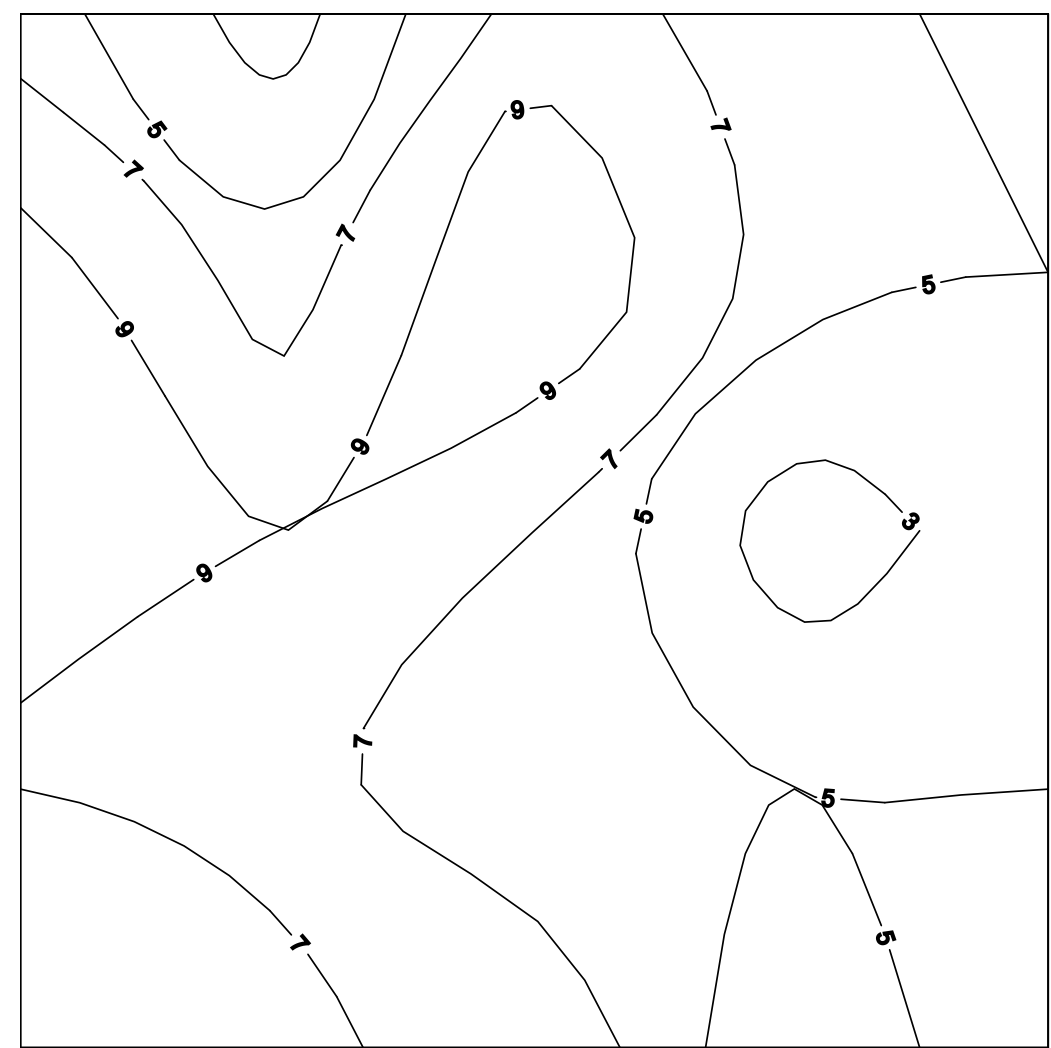

Figure 7. Magnetic Lineaments Density Contour Mapof the Study Area(Contour Interval is 0.01) 


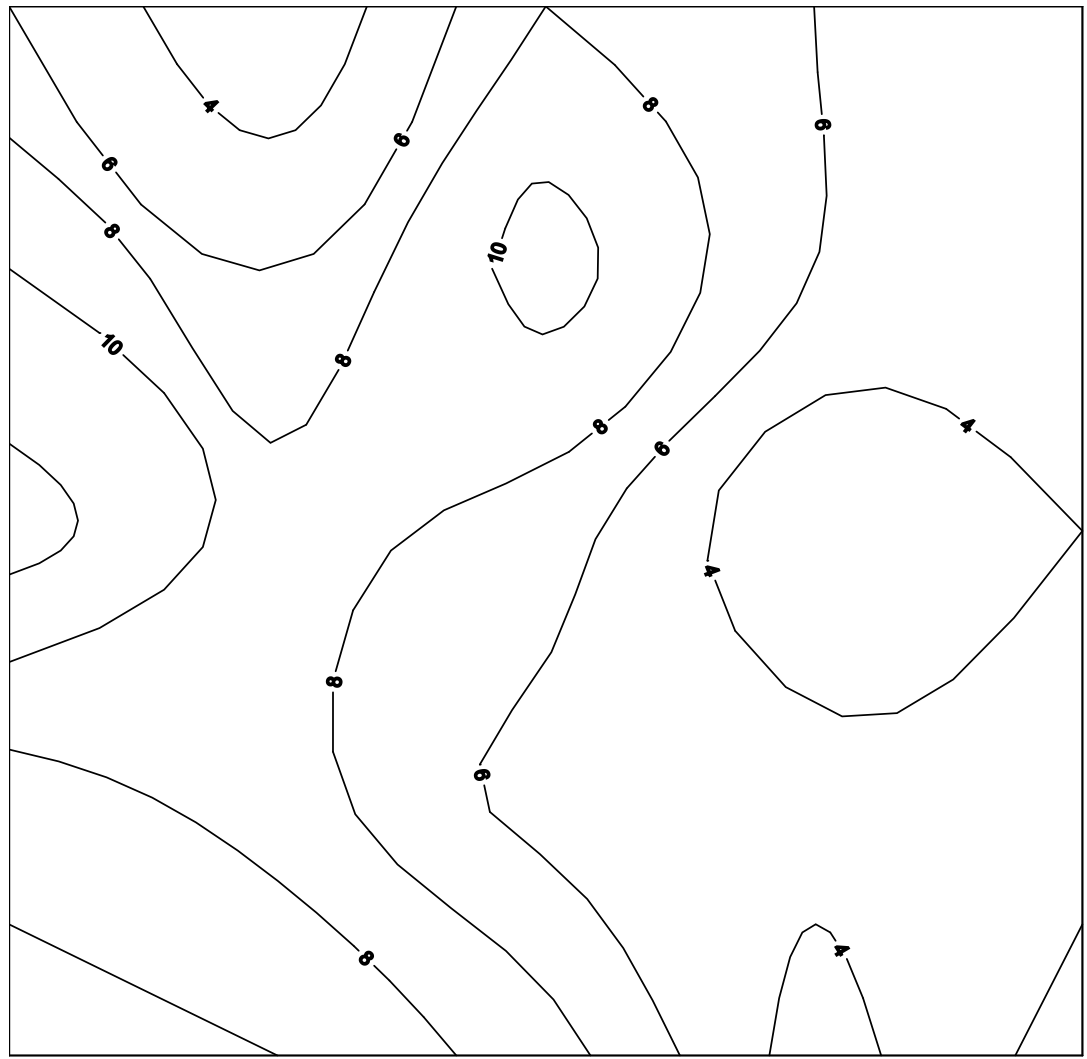

Figure 8. Surface Lineaments Density Mapof the Study Area(Contour Interval is 0.02).

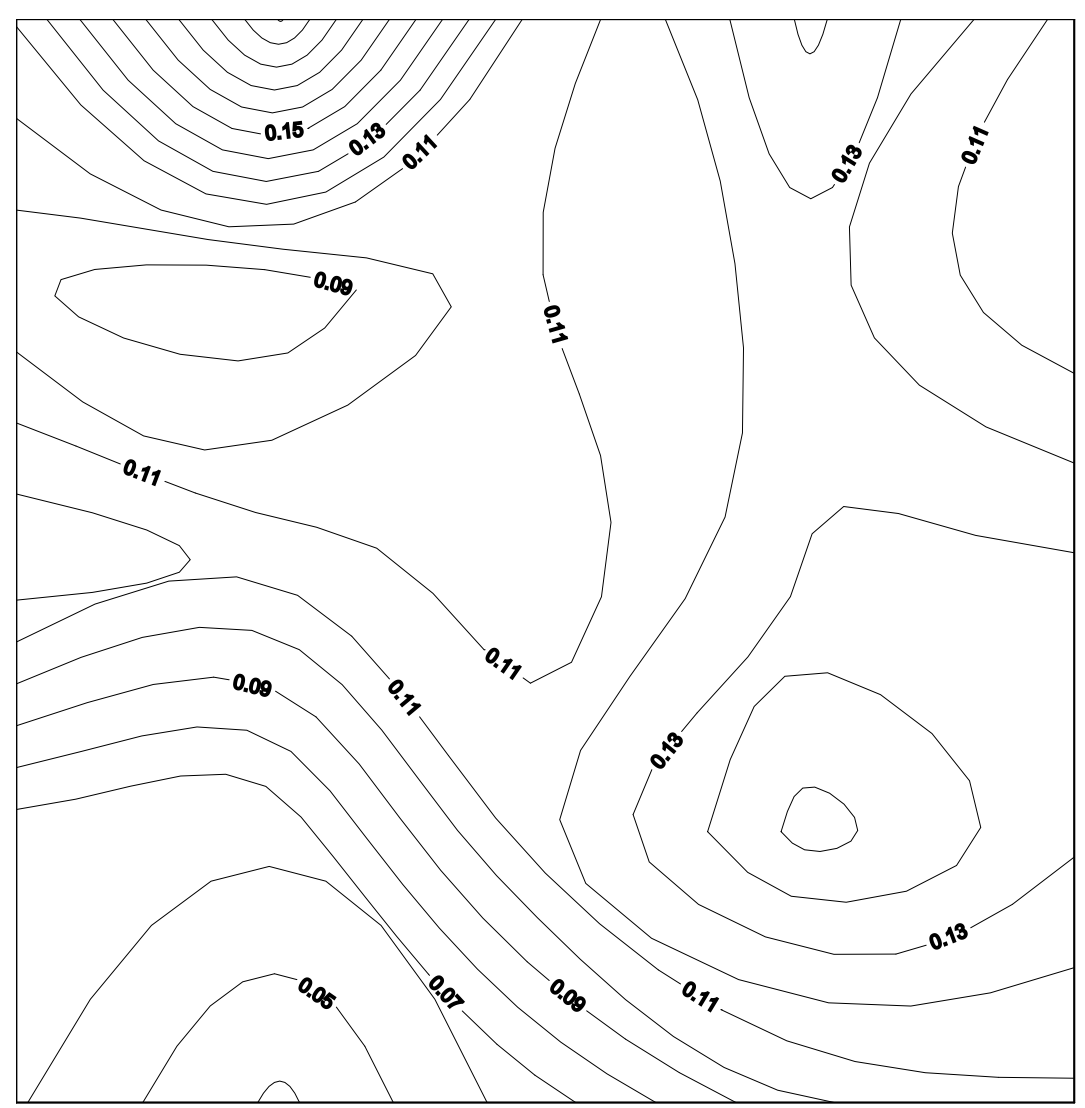

Figure 10.Magnetic lineament length density contour map of the Study Area. (Contour Interval is 0.01 ) 


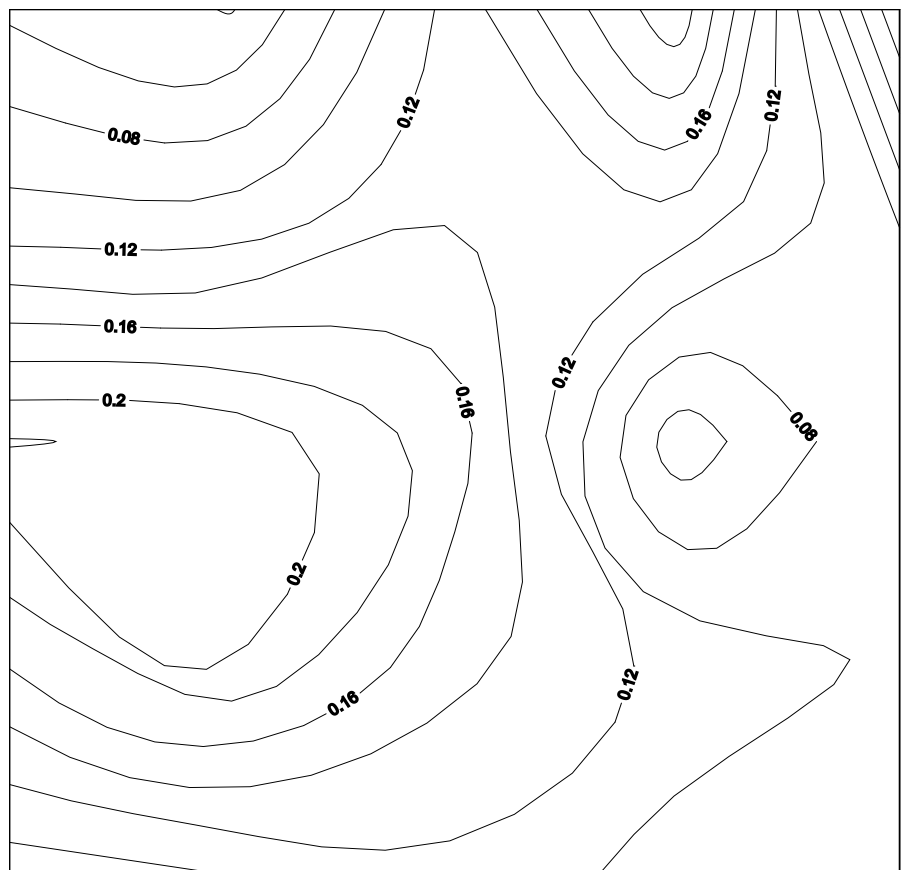

Figure 11. SurfaceMagnetic lineament length density contour map of the Study Area. (Contour Interval is 0.02)

Magnetic and surface length densities suggests that the area was inferred to reflect variations in the intensity of different stress regimes that affected the area at different geological times.

The rose diagrams of the magnetic and surface lineaments for the whole portion and different sections of the study area (Figs. 12 and 13) showed five main lineament sets in the study area with the major lineament sets along NE-SW, E-WNNE-SSW and NW-SE directions and a minor trend along ENE-WSW direction. Coincidence of NE-SW trend, as a major trend among the magnetic and surface trends was interpreted to reflect real propagation of the surface fractures in depth. The conjugate sets of the NE-SW and NW-SE lineaments represent the most frequent and wide spread trends and the NNE-SSW and the ENE-WSWrepresent the least frequent trends in the areawhile the E-W trend was observed to reflect the most obliterated trend. The epeirogenesis of these lineaments has been associated with the stress regime associated with the pre-PanAfrican and Pan-African tectonic events ([12], [16], [17]). However, the lineaments were later reactivated, in the Benue trough during the Late Cretaceous and Santonian deformations era ([12]).Thus the delineation of these trends in the study area and other parts of northern Nigerian basement complex [9] suggests that the tectonic activities of the early Cretaceous and Santonian periods beneath the Benue trough have extended beneath the northern Nigerian basement complex region. It is pertinent to mention that the trends of the inferred lineaments in this study correlate with the structural trends earlier inferred in the Northern Nigerian basement complex region, Nigerian Younger Granite province and the Benue trough (e.g. [8], [9], [12], [19], [20]).

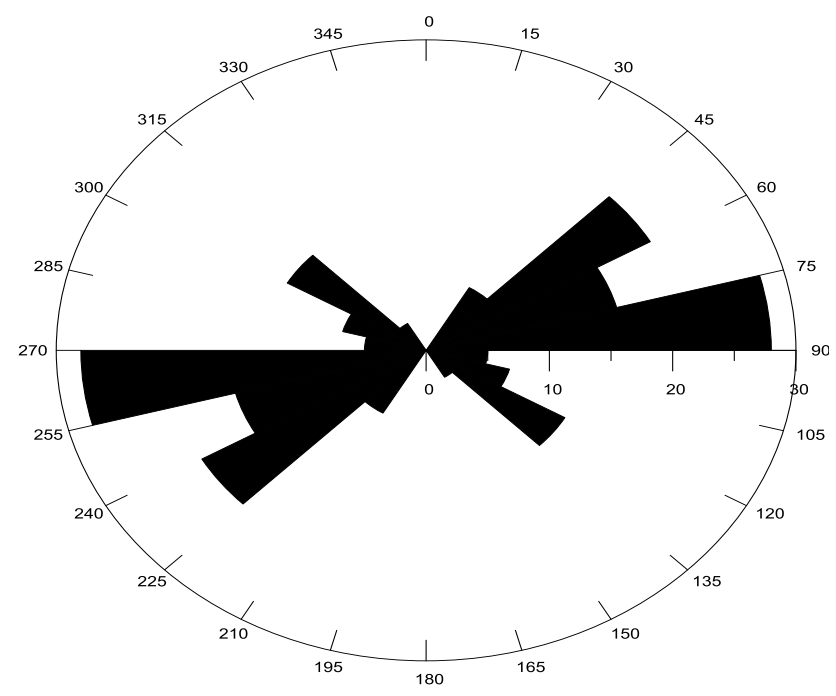

Figure 12a. Rose Diagram for the Inferred Magnetic Lineaments for the Whole Area 


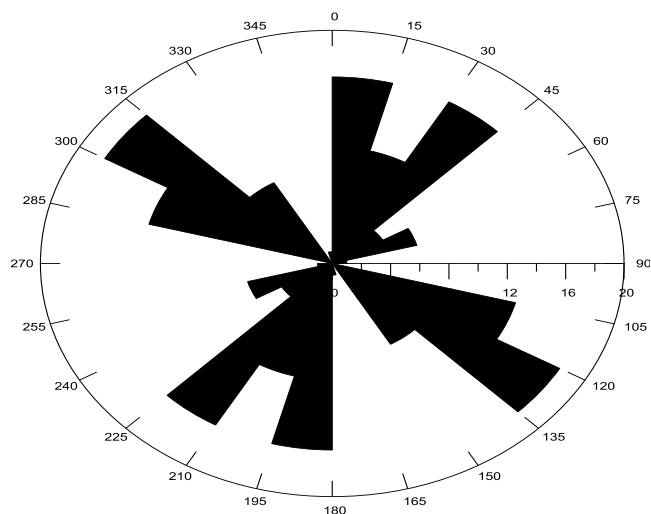

Figure 12b. Rose Diagram for the Surface Lineaments for the Whole Area.

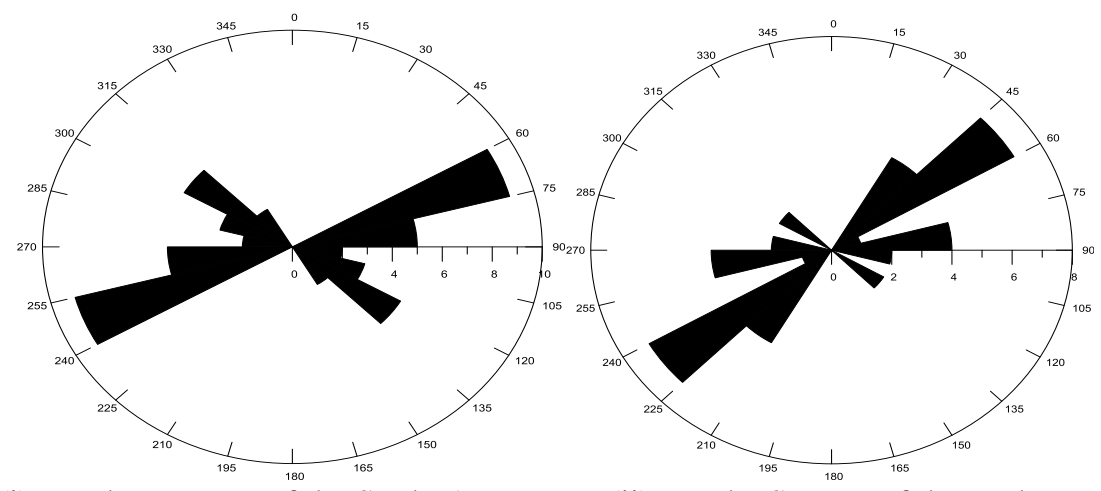

(i) For the NE Part of the Study Area

(ii) For the SE part of the study area

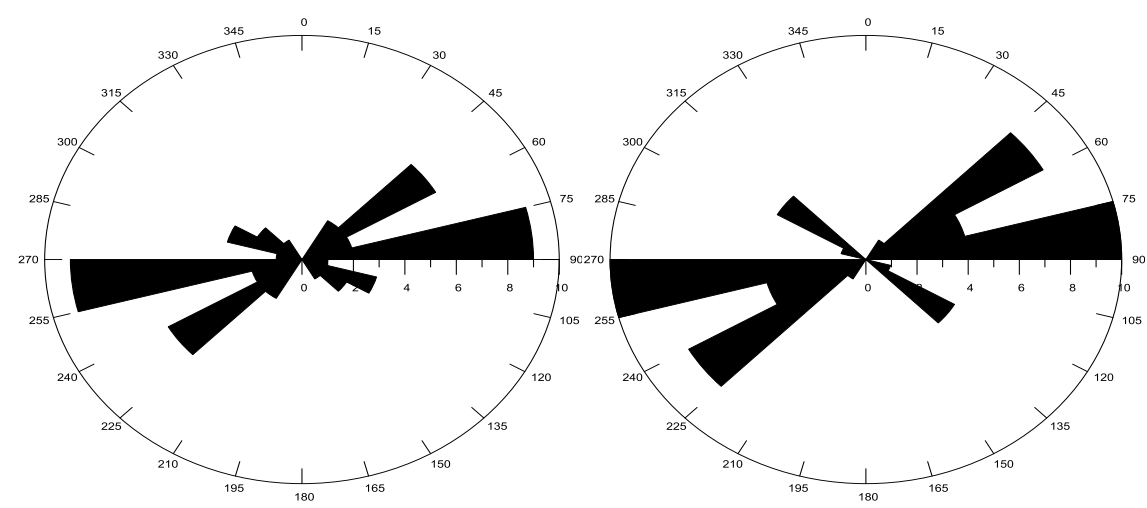

(iii) For the SW Part of the Study Area (iv) For the NW Part of the Study Area

Fig. 13a. Rose Diagram for the Magnetic Lineaments in Different Parts of the Study Area.

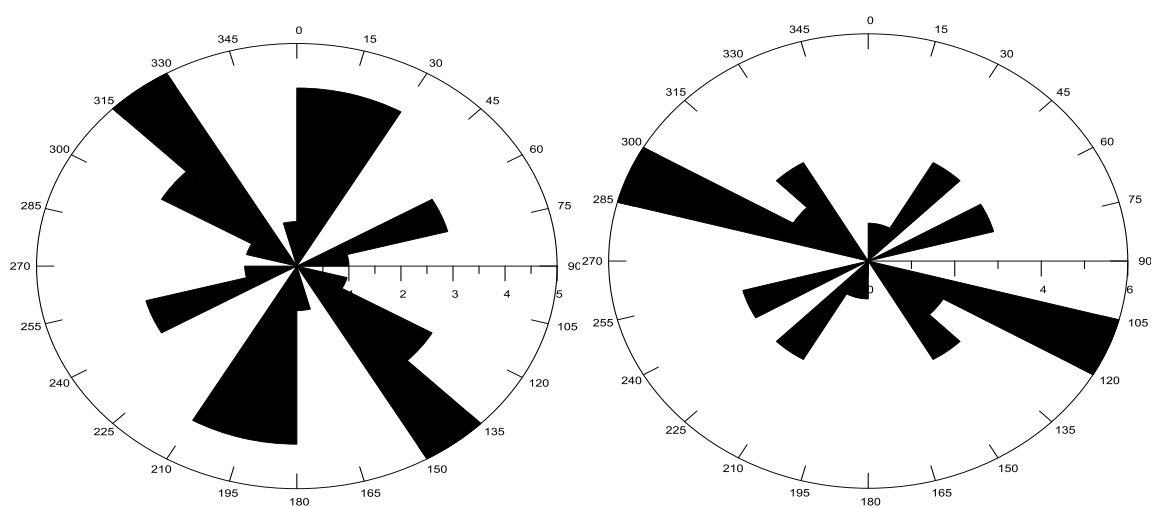

(i) For the NE Part of the Study Area (i) For the SE Part of the Study Area 


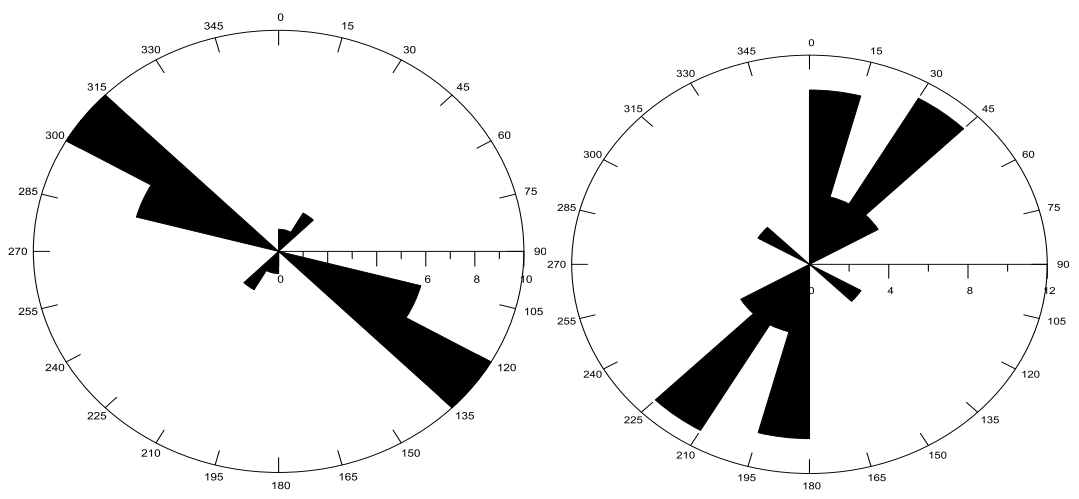

(iii) For the SW Part of the Study Area(i) For the NW Part of the Study Area

Fig. 13b. Rose Diagram for the Surface Lineaments in Different Parts of the Study Area.

\section{Conclusion}

The main conclusion that can be drawn from this study is that basement surface of the study area has been affected by different stress regime in different geological times which resulted in the reactivation of various ancient faults oriented along different directions. Some of these ancient faults were inferred to have exerted structural control on some surface faults.

\section{References}

[1]. Carter, J. D., Barber, W. and Tait, E. A. (1963). The geology of parts of Adamawa, Bauchi and Borno Provinces in Northern Nigeria. Bulletin of Geological Survey of Nigeria. 30

[2]. Jacobson, R. R. E., Macleod, M. W. and Black, R. (1958). Ring complexes of younger granite province of northern Nigeria. Geological Survey of London Memoir, 172.

[3]. Oyawoye, M. O. (1964). The geology of the Nigerian basement complex. Journal of Mining and Geology and MetallurgicalSociety. $\mathbf{1}(2) ; 87-103$.

[4]. Ajakaiye, D. E. (1974). Gravity survey over the Nigerian younger granite province. In C. A. Kogbe(Ed); Geology of Nigeria:(287294. Elizabethan Publishing Company Lagos.

[5]. Hunt, G. R., Salisbury, J. W. and Len Hoff, C. J. (1974). Visible and near infrared spectra of minerals and rocks. Modern Geology, 5: $15-22$

[6]. Ananaba, S. E. and Ajakaiye, D. E. (1987). Evidence of tectonic control of mineralization in Nigeria from lineament density analysis: A landsat study. International Journal of Remote Sensing.8(10): 1445-1453.

[7]. Odia, B. E. (1989). Regional magnetic lineaments in the younger granite province of northern Nigeria. Journal of Mining and Geology, 25 (1\&2): 233- 240.

[8]. Ajakaiye, D. E., Hall, D. H., Miller, T. W., Verheigen, P. J. T., Awad, M. B and Ojo, S. B. (1986). Magnetic Anomalies and Tectonic Trends in and around the Benue Trough. Nature.319: $582-584$.

[9]. Olasehinde, P. I., Pal, P. C. and Annor, A. E. (1990). Aeromagnetic anomalies and structural lineaments in the Nigerian Basement Complex. Journal of African Earth Sciences, 3(4): 351-355.

[10]. Tarlowski, C., Gunn, P. J. and Mackey, T. (1997). Enhancement of magnetic map of Australia. Journal of Australian Geology and Geophysics, 17(2): 77- 82.

[11]. Blakely, R. J. (1995). Potential field theory in gravity and magnetic applications. Cambridge University Press, USA. 441pp.

[12]. Anudu, G. K., Stephenson, R. A. and David, I. M. (2014). Using high resolution aeromagnetic data to recognize and map intrasedimentary volcanic rocks and geologic structures acrocc Cretaceous middle Benue trough, Nigeria. Journal of African Earth Sciences, 16 (1): $1-12$.

[13]. Ghazala, H. H. (1993).. Geological and structural interpretation of airbone surveys and its significance for mineralization, SouthEastern desert, Egypt. Journal of African Earth Sciences, 16(3): 273- 284.

[14]. Edet, A. E., Teme, S. E., Okereke, S. C. and Esu, E. O. (1994). Lineament analysis for groundwater exploration in precambrian Oban massif and Obudu plateau, SE Nigeria. Journal of Mining and Geology, 30 (1): 87- 95.

[15]. Karnieli, A., Meisels, A., Fisher, L. and Arkin, Y. (1996). Automatic extraction of geologic linear features from digital remote sensing data using a Hough transform. Photogrammetric Engineering and Remote Sensing, 62: 525 - 531.

[16]. Genik, G. J.(1992). Regional framework and structural aspects of the rift basins in Niger, Chad and Central African Republic (C. A. R). In P. A. Zeigler (Ed.); Geodynamics of Rifting, Volume II. Case History Studies on Rifts: North and South America and Africa.Tectonophysics 213:169-185.

[17]. Obiora, S. C. (2009). Field measurements in description of igneous and metamorphic rocks. In Lambert-Aikhionbare, D. O. and Olayinka, A. I. (eds). Proceedings of field mapping standardization workshop, Ibadan University press: pp 105- 125.

[18]. Avbovbo, A. A., Ayoola, E.O. and Osahon, G. A. (1986). Depositional Structural Styles in the Chad Basin of Northeastern Nigeria. Bull. American Association of Petroleum. Geology.70: 1787 - 1798

[19]. Onyedim, G. C., Alagoa, K. D., Adedokun, I. O., Aderogba, A. A. and Ovuru, C. (2009).

[20]. Mapping high-angle basement faults in the Middle Benue Trough, Nigeria from gravity inversion surface. Earth Science Research Journal.13(2): 140 - 147.

[21]. Alkali, S. C. and Gaiya, S. (2011). Delineation of linear structures from digitized aeromagnetic data of the western part of the Younger Granite Complex of North Central Nigeria. New-York Science Journal,4(9): 56 -62. 